Уголовное право. Уголовный процесс. Криминалистика

УДК 343.85

DOI https://doi.org/10.17308/vsu.proc.law.2020.3/2993

\title{
МЕРЫ ПРОФИЛАКТИКИ КРИМИНАЛЬНОГО СУИЦИДА НЕСОВЕРШЕННОЛЕТНИХ
}

\author{
М. Ю. Пучнина \\ Воронежский институт МВД России \\ Поступила в редакцию 20 февраля 2020 г.
}

\begin{abstract}
Аннотация: раскрываются методика и механизл склонения несовершеннолетних к салоубийству в сети "Интернет", установлены основные характерные черты данного явления, расслотрены основные направления предупреждения крилинальных суицидов несовершеннолетних, а также сфборлулированы предложения, направленные на совершенствование проводилой профблактической работы в указанной сфбере.

Ключевые слова: криминальный суицид, несовершеннолетние, социальныєе сети, "группь смерти», профбилактика.
\end{abstract}

\begin{abstract}
: the article reveals the methodology and mechanism of inducing minors to suicide on the Internet, the main characteristics of the phenomenon are established, the main directions for the prevention of juvenile crime are considered, and proposals are made that are aimed at improving preventive work in this area.

Key words: criminal suicide, minors, social networks, "death groups", prevention.
\end{abstract}

Любое самоубийство - это трагедия. По данным Всемирной организации здравоохранения (далее - ВОЗ), ежегодно более 800000 человек заканчивают жизнь самоубийством ${ }^{1}$. Это имеет крайне негативные и далеко идущие последствия для родных и близких суицидента, даже спустя долгое время после сведения им счетов с жизнью. Необходимо отметить, что в мировом масштабе среди причин смерти молодых людей в возрасте от 15 до 29 лет самоубийства занимают второе место.

Несмотря на то что само по себе самоубийство абсолютно индифферентно для юридических наук, тем не менее отдельные авторы выделяют такую разновидность исследуемого понятия, как криминальный суицид ${ }^{2} .285$ В нашем понимании это такое самоубийство, причиной которого высту-

\footnotetext{
${ }^{1}$ Предотвращение самоубийств : глобальный императив. Женева, 2014. С. 6.

${ }^{2}$ См.: Гавло В. К., Градусова M. М. Криминальный суицид в вопросах квалифоккации преступлений по ст. 205 и 205.1 УК РФ // Известия Алтайского гос. ун-та. 2011. № 2-2 (70). С. 89-92 ; Бозров В. М., Костовская Н. В., Яворский А. А. Криминальный суицид (психолого-психиатрические, уголовно-правовые и процессуально-криминалистические аспекты). М., 2015 ; Иванченко Р. Б., Польшиков А. В. Медико-социологические, уголовно-правовые и криминологические аспекты понятия «криминальный суицид» // Вестник Воронеж. ин-та МВД России. 2017. № 4. C. $45-51$.
}

(C) Пучнина М. Ю., 2020 


\section{Вестник ВГУ. Серия: Право}

пает внешнее негативное воздействие физического, психического или информационного характера, не исключающее возможности суицидента осознавать фактический характер и значение совершаемых действий, их возможные последствия и руководить ими (в том числе отказаться от их осуществления).

Возрастной период с 12 до 18 лет - самый опасный, потому как наблюдается процесс становления личности - пубертатный период, когда происходит активный выброс гормонов, меняется телосложение, внешность. Усиливается влияние социальных ролей, дети ищут идеальную модель поведения. Происходит усиление депрессивных черт, одновременно с этим в коллективе формируется групповое давление. Становление личности подростка происходит через призму отношений в референтной группе ${ }^{3}$. Если он не находит этой самоидентификации в семье или школе из-за равнодушия сверстников либо постоянных конфликтов дома, он находит ее в сети «Интернет». Общаясь там, несовершеннолетний поначалу обретает чувство комфорта от того, что его интересы и взгляды разделяют, а также оказывают поддержку4. У подростка складывается впечатление, что лучше всего его понимают именно там, в виртуальном пространстве.

В настоящее время число самоубийств несовершеннолетних сохраняется на достаточно высоком уровне. Сама по себе данная проблема может быть обусловлена рядом факторов, куда входят и проблемы в семье, школе, сложность в общении со сверстниками, недостаток внимания, неразделенная любовь и т. д. Также думается, что подобная неадекватная реакция на трудную ситуацию, сложившуюся вокруг ребенка, часто спровоцирована правонарушениями в отношении подростка. К числу таких провоцирующих факторов можно отнести появление в социальных сетях м «групп смерти». Обозначенные сообщества через наиболее популярные у 일 несовершеннолетних информационные ресурсы сети «Интернет» пропагандируют культ смерти, оправдывают подростковый суицид и обманом предлагают его ребенку в качестве самого доступного и «правильного» выхода из любой сложной жизненной ситуации.

Довольно часто такая информация преподносится в игровой форме (наиболее доступной форме с точки зрения детской психологии и педагогики), которая позволяет сделать жертвами детей самого младшего возраста. Яркий пример тому - интернет-игра «Синий кит», которая заключается в поэтапном выполнении подростками определенных заданий от руководителя интернет-сообщества (как правило, взрослый наставник по игре в соответствующей «группе смерти») суицидальной тематики: чтение специализированной литературы, изучение криповых (угнетающих)

${ }^{3}$ См.: Криминология : учеб. пособие / под ред. В. Д. Малкова, В. А. Лелекова. Воронеж, 2005. С. 102-109.

${ }^{4}$ См.: Польшиков А. В., Буданова E. А. Проблемы предупреждения преступлений, связанных с вовлечением несовершеннолетних в совершение антиобщественных действий // Вестник Воронеж. ин-та МВД России. 2018. № 2. С. 202-209. 
аудио- и видеоматериалов, фотоизображений, нанесение себе увечий (селфххарм), чтобы ребенок мог постепенно побороть чувство страха за свою жизнь и т. п. ${ }^{5}$ Все вышеперечисленное представляет большую опасность, поскольку может побудить подростков к совершению действий, представляющих угрозу их жизни и (или) здоровью, в том числе к самоубийству или попытке самоубийства ${ }^{6}$. По данным экспертов, осуществлявших мониторинг в сети «Интернет» на предмет наличия запрещенного контента, в настоящее время действует до трех тысяч таких суицидальных сообществ ${ }^{7}$.

Проведенный контент-анализ информационного пространства сети «Интернет» позволил определить типичного участника «группы смерти» - это ведомый, неуверенный в себе подросток с большим количеством комплексов. Внешность, вес, очки и прочее. Как правило, он не выставляет свои реальные фотографии напоказ: размещено не более двух фото либо их нет вообще. Страница такого подростка содержит изображения, которые можно отнести к суицидальной тематике либо в которых прослеживается данное течение.

Согласимся с мнением экспертов, что «группы смерти» действительно оказывают достаточно большое влияние на подрастающее поколение, однако, на наш взгляд, их влияние на подростковый суицид следует относить не к причинам, а к условиям, потому как деятельность указанных интернет-сообществ заключается в подталкивании к самоубийству путем оказания психологического давления ${ }^{8}$. Общаясь с несовершеннолетними, «кураторы» выявляют реальные проблемы жертвы, после чего преувеличивают их в разы и буквально убеждают: «Другого выхода нет!».

Для разработки әфффективной программы профилактики подростковых самоубийств необходимо определить основные характерные черты суицидального поведения. В результате изучения специализированной литературы ${ }^{9}$ были выделены и составлены следующие признаки, свойственные большинству несовершеннолетних суицидентов:

${ }^{5}$ См.: Киселев C. С. «Группы смерти» в современном обществе потребления и бессилие правовой системы России // Право, государство и экономика : проблемы теории, истории и практики : материалы Всероссийской науч.-практ. конф. Краснодар, 2017. С. 139-142.

${ }^{6} \mathrm{O}$ защите детей от информации, причиняющей вред их здоровью и развитию : федер. закон от 29 декабря 2010 в № 436-ФЗ (в ред. от 29.07.2015) // Собр. законодательства Рос. Федерации. 2011. № 1. Ст. 48.

${ }^{7}$ См.: Детский суицид : фракторы защиты и риски : метод. рекомендации. Воронеж, 2017.

${ }^{8}$ См.: Киселев С. С. Киберпреступления против жизни и здоровья в обществе потребления. Первая ласточка // Уголовная политика и культура противодействия преступности : материалы Междунар. науч.-практ. конф. Краснодар, 2017. C. 252-255.

${ }^{9}$ См.: Волкова А. Н. Психолого-педагогическая поддержка детей-суицидентов // Вестник психосоциальной и коррекционно-реабилитационной работы. 1998. № 2. C. 36-43 ; Shneidtnan E. Definition of Suicide. New York, 1985. 


\section{Вестник ВГУ. Серия: Право}

- внешний вид: задумчивость, краткость либо отсутствие ответов, повышенная сонливость, заторможенность, слезливость, демонстрация радикальных перемен (был опрятным - стал неряшливым, ел слишком много - теперь слишком мало, то чрезмерно активен - то пассивен, то испытывает әйфорию, то приступы отчаяния) и т. д.;

- словесные признаки: подросток прямо и без стеснения говорит о смерти («я не могу так больше жить»), косвенно намекает о своем намерении («тебе больше не придется обо мне волноваться»), много шутит на тему суицида, проявляет нездоровую заинтересованность вопросами смерти;

- поведенческие признаки: несовершеннолетний раздает друзьям и знакомым вещи, которые имеют большое значение для него, прощает долги, мирится с давними врагами, старается привести в порядок свои незаконченные дела, склонен к одиночеству либо, наоборот, необъяснимо желает побыть с родными и близкими и т. д.

Следует также отметить, что немаловажной и характерной чертой суицида несовершеннолетних является стремление быть свидетелем реакции окружающих на свою смерть либо надежда на "второе рождение»" ${ }^{10}$. Подросток воспринимает смерть как длительное отсутствие или иное существование. Как указывает по этому поводу Е. М. Вроно: «..желание устраниться лишь на время, «умереть не до конца» - типичное подростковое решение трудной ситуации» ${ }^{11}$. Суицидальный поступок воспринимается в романтически-героическом ореоле: как смелый вызов, решение, которое может принять только сильный человек, и т. д.

Большую роль играет также пессимистическая установка ${ }^{12}$ - это когда подросток, пытаясь привлечь внимание, начинает демонстрировать свое пренебрежительное отношение к себе и своей жизни; если не послене переубеждает в обратном, такой настрой может стать доминирующим над желанием жить и справляться с возникающими трудностями.

Рассмотрев некоторые наиболее значимые черты и признаки суицидального поведения, можно сделать вывод, что самоубийство является крайней формой отклоняющегося поведения личности, ее социально-психологической адаптации ${ }^{13}$. Как правило, самоубийство не совершается при наличии лишь одной причины или сопутствующего условия, чаще всего присутствует их сочетание, а это, в свою очередь, уве-

${ }^{10}$ См.: Киселев С. С. Мода на смерть : опасность и предотвращение // Феноменология и профилактика девиантного поведения : материалы XI Междунар. науч.-практ. конф. Краснодар, 2018. С. 102-106.

${ }^{11}$ Вроно E. M. Об особенностях суицидального поведения подростков с различными типами депрессий : автореф. дис. ... канд. мед. наук. М., 1984.

12 См.: Вихристюк О. В. Что нужно знать родителям о подростковых суицидах? М., 2013. С. 67.

${ }^{13}$ См.: Николаева Ю. В. Государственная политика в сфере обеспечения интересов несовершеннолетних (историко-правовые и теоретические проблемы). М., 2007. 
личивает вероятность завершенной попытки. Подростковому суициду свойственны различные мотивы и поводы, но, как правило, они всегда вытекают из внутриличностного конфликта либо конфликта с окружающей средой, когда индивид не может разрешить возникшую проблему иным путем.

В подавляющем большинстве случаев суицидальное поведение в возрасте до 15 лет связано с реакциями протеста, частым источником которых являются нарушенные внутрисемейные, внутришкольные или внутригрупповые взаимоотношения. Однако вышесказанное не означает, что правоохранительным органам и представителям общественности не стоит вовсе вести активную работу по пресечению деятельности деструктивных интернет-сообществ и «групп смерти».

На наш взгляд, исходя из специфики фракторов, обусловливающих криминальные суициды несовершеннолетних, необходимо разделять объекты и направления профилактического воздействия (например, помощь подростку в разрешении внутриличностных, внутрисемейных или групповых конфликтов посредством усиления психолого-педагогической работы с семьей и в школе, противодействие деструктивным интернет-сообществам со стороны органов и учреждений системы профилактики, проведение ранней профилактики в общеобразовательных организациях с привлечением представителей заинтересованных субъектов профолактики, комплексная поддержка на государственном уровне деятельности общественных объединений и правозащитных организаций в борьбе с подростковыми суицидами).

Сотрудники полиции во взаимодействии с образовательными организациями должны оказывать помощь молодежным движениям и общественным организациям в подготовке и проведении различных акций, целью которых должна стать пропаганда здорового образа жизни, поскольку меры, направленные на повышение духовно-нравственного и культурного уровня, правосознания молодежи, способствуют эффективной профилактике подростковых суицидов, а также иных деструктивных форм поведения.

К профилактической работе по мониторингу социальных сетей на предмет суицидального контента целесообразно привлекать на добровольной основе активистов из числа учеников старших классов, обучающихся колледжей, студентов вузов. Успешная реализация данной меры возможна только при активном взаимодействии с представителями органов управления образованием, наукой и молодежной политикой региона, общественными организациями, а также администрациями конкретных образовательных организаций. Практика показывает, что такая работа вызывает огромный интерес у всех участников.

Положительным примером успешной организации такого вида деятельности является всероссийское движение «Сдай педофила» ${ }^{14}$, зародившееся в г. Воронеже, которое тесно сотрудничает с Роскомнадзором

${ }^{14}$ URL: https://vk.com/sdai_pedofila (дата обращения: 20.08.2017). 


\section{Вестник ВГУ. Серия: Право}

и правоохранительными органами. Работа в основном осуществляется волонтерами, которым небезразлична судьба подрастающего поколения (к настоящему времени волонтеры движения работают в Калуге, Екатеринбурге, Петербурге, Нижнем Новгороде, Краснодаре, Сочи, Новосибирске). Просматривая страницы социальных сетей подростков, они выявляют тех, кто может стать жертвой преступления либо является таковой (здесь речь идет о педофилии), а также сомнительные аккаунты взрослых, которые могут выступать преступниками в данной среде.

Еще одним ярким представителем такой деятельности являются «кибердружины» - группы людей, которые противодействуют интернет-сообществам, ведущим агитацию и склонение подростков к самоубийству (они относят себя к приверженцам группы «Китобой» либо называют себя «Дельфинами»). Наиболее известными среди них являются проект «МедиаГвардия» в Республике Башкортостан и движение волонтеров «Киберпатруль» в Тюменской области. Основная их деятельность направлена на поиск запрещенного контента в сети «Интернет» и передачу информации о нем в правоохранительные органы и Роскомнадзор.

В конечном счете профилактическая работа не должна вызывать панику у родителей и других законных представителей несовершеннолетнего. Важно вовремя объяснить им, как правильно реагировать на появившийся у ребенка интерес к таким интернет-сайтам, установить с ребенком доверительные отношения и к кому следует обратиться, чтобы спасти ребенка в случае появления реальной опасности (информации о готовящемся суициде или иных противоправных действиях в отношении подростка). В этих целях сотрудниками полиции в общеобразовательных организациях и в высших учебных заведениях для 1-2-го курсов прово-

일 дятся беседы, круглые столы, лекции для несовершеннолетних и их ро․ дителей (законных представителей), педагогов, воспитателей.

尺े Современный человек при создавшейся иллюзии большой свободы выбора в действительности стал более зависим от окружающего мира. Отношение общества к самоубийцам в разные исторические периоды

290 было различным: от поощрительного, разрешительного до запретного. При этом не обязательно рассматривать отношение общества в целом к суицидам, достаточно мнения какой-либо одной социальной группы (например, подростков). Кроме того, оно может быть не постоянным, а временным, что наблюдается в настоящее время: «группы смерти» привлекают внимание несовершеннолетних, а, вступая в них, подростки часто изменяют свою оценку и воззрения касательно самоубийства вообще.

Подростковый суицид является острой и социально значимой проблемой современного общества. Его профилактика должна представлять систему комплексных мероприятий, направленных на сохранение и совершенствование условий, обеспечивающих благополучное развитие 
Уголовное право. Уголовный процесс. Криминалистика

подрастающего поколения. Сочетание существующих и предлагаемых методов будет способствовать повышению эфффективности профилактики как криминальных, так и некриминальных суицидов несовершеннолетних.

Воронежский институт МВД России

Пучнина М. Ю., кандидат юридических наук, преподаватель кафбедры уголовного процесса

E-mail: masloy100@mail.ru
Voronezh Institute of the Russian Ministry of Internal Affairs

Puchnina M. Yu., Candidate of Legal Sciences, Lecturer of the Criminal Process Department

E-mail: masloy100@mail.ru 